\title{
Sedimentation Survey of Lago Carite, Puerto Rico, October 1999
}

Water-Resources Investigations Report 00-4235

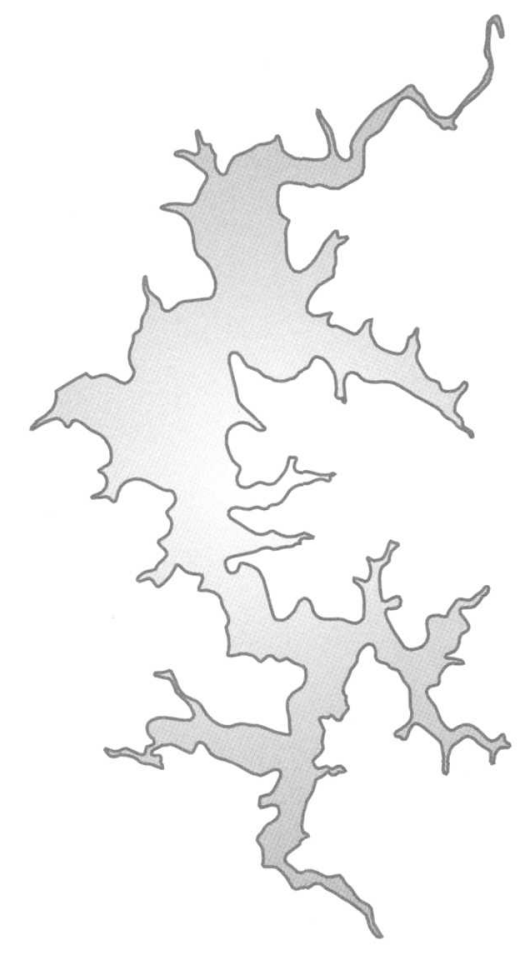




.
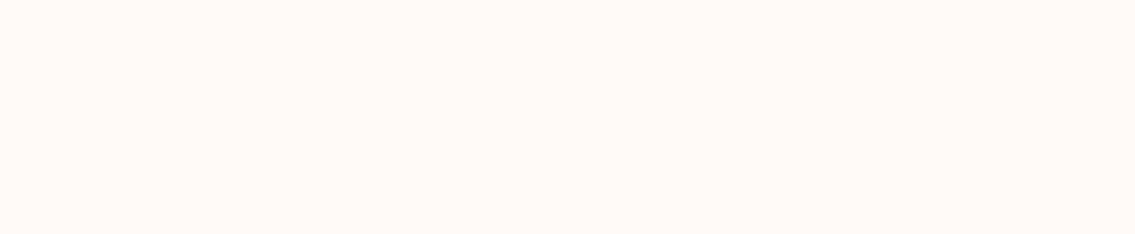
(1)

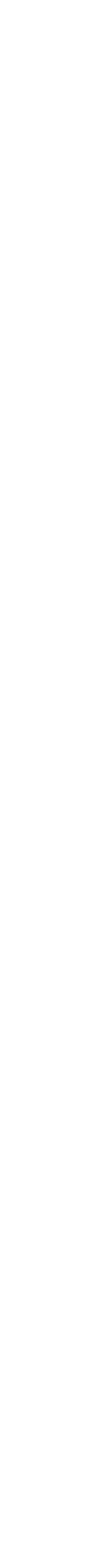

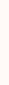




\section{Sedimentation Survey of Lago Carite, Puerto Rico, October 1999}

By Luis R. Soler-López and Ramón A. Carrasquillo-Nieves

Water-Resources Investigations Report 00-4235

In cooperation with the PUERTO RICO ELECTRIC POWER AUTHORITY 


\section{U.S. DEPARTMENT OF THE INTERIOR \\ BRUCE BABBITT, Secretary}

\section{U.S. GEOLOGICAL SURVEY}

Charles G. Groat, Director

Use of trade names in this report is for identification purposes only and does not imply endorsement by the U.S. Government.

For additional information write to:

Copies of this report can be purchased from:

District Chief

U.S. Geological Survey

GSA Center, Suite 400-15

651 Federal Drive

Guaynabo, Puerto Rico 00965

U.S. Geological Survey

Branch of Information Services

Box 25286

Denver, CO 80225 


\section{CONTENTS}

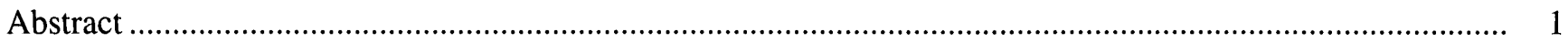

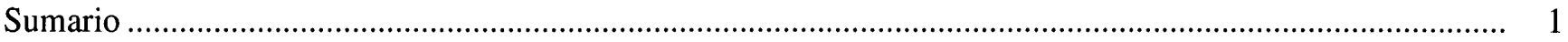

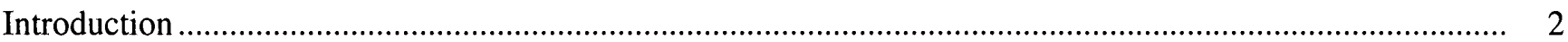

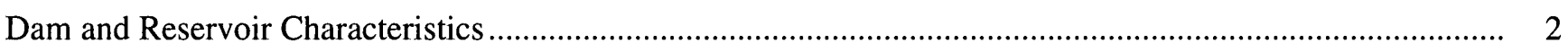

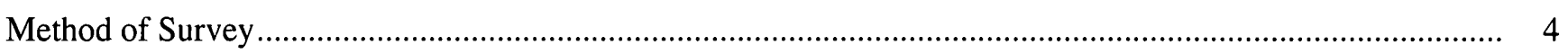

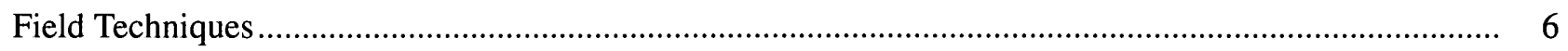

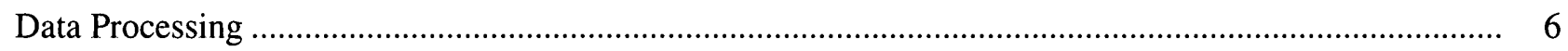

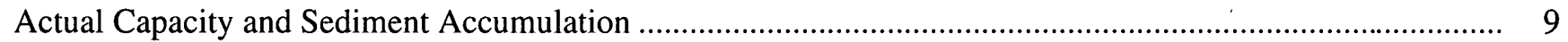

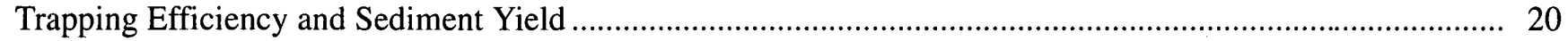

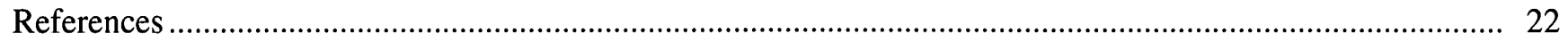

\section{PLATES}

[Plate is in pocket]

1. Lago Carite, Puerto Rico, Bathymetry, October 1999 


\section{FIGURES}

\section{1.-5. Map showing}

1. Location of Lago Carite in the Río de la Plata basin, Puerto Rico

2. Planned cross-section locations for the October 1999 bathymetric survey of Lago Carite, Puerto Rico

3. Actual track lines of the October 1999 bathymetric survey of Lago Carite, Puerto Rico

4. Distances from the dam along the different branches of Lago Carite, Puerto Rico

5. Selected cross-section locations for the October 1999 bathymetric survey of Lago Carite, Puerto Rico

6. Selected cross sections generated from the October 1999 TIN surface model of Lago Carite, Puerto Rico.

7. Longitudinal profiles generated from the October 1999 TIN surface model of Lago Carite, Puerto Rico, along the thalweg of the different branches of the reservoir.

8. Lake elevation-storage capacity curve for Lago Carite, Puerto Rico, for October 1999

9. Storage capacity to inflow relation established by Brune in 1953

\section{TABLES}

1. Principal characteristics of Lago Carite and dam, Puerto Rico, as of 1988

2. Comparison of the 1913, 1986, and the October 1999 bathymetric surveys of Lago Carite, Puerto Rico

3. Available storage capacity, as a function of lake elevation, for Lago Carite, Puerto Rico, for October 1999 


\begin{tabular}{|c|c|c|}
\hline Multiply & By & To obtain \\
\hline \multicolumn{3}{|c|}{ Length } \\
\hline centimeter & 0.03281 & foot \\
\hline meter & 3.281 & foot \\
\hline kilometer & 0.6214 & mile \\
\hline \multicolumn{3}{|c|}{ Area } \\
\hline square meter & 10.76 & square foot \\
\hline square kilometer & 0.3861 & square mile \\
\hline square kilometer & 247.1 & acre \\
\hline \multicolumn{3}{|c|}{ Volume } \\
\hline cubic cemtimeter & 0.06102 & cubic inch \\
\hline cubic meter & 35.31 & cubic foot \\
\hline cubic meter & 0.0008107 & acre-foot \\
\hline million cubic meters & 810.7 & acre-foot \\
\hline \multicolumn{3}{|c|}{ Volume per unit time (includes flow) } \\
\hline cubic meter per second & 35.31 & cubic feet per second \\
\hline cubic meter per second & 15,850 & gallon per minute \\
\hline cubic meter per second & 22.83 & million gallons per day \\
\hline \multicolumn{3}{|c|}{ Mass per area (includes sediment yield) } \\
\hline gram per cubic centimeter & 62.43 & pound per cubic foot \\
\hline kilogram per square kilometer & 0.002855 & ton per square mile \\
\hline megagram per square kilometer & 2.855 & ton per square mile \\
\hline
\end{tabular}

\section{Datums}

Horizontal Datum - Puerto Rico Datum, 1940 Adjustment

Sea level: In this report, "sea level" refers to the National Geodetic Vertical Datum of 1929 (NGVD of 1929) — a geodetic datum derived from a general adjustment of the first-order level nets of the United States and Canada, formerly called "Seal Level Datum of 1929".

\section{Acronyms used in this report}

\section{BLASS Bathymetric/Land Survey System}

DGPS Differential Global Positioning System

GIS Geographic Information System

PREPA Puerto Rico Electric Power Authority

TIN Triangulated Irregular Network

USGS U.S. Geological Survey 


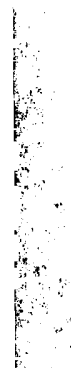

$\mathbb{k}$

,

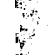




\title{
Sedimentation Survey of Lago Carite, Puerto Rico, October 1999
}

\author{
By Luis R. Soler-López and Ramón A. Carrasquillo-Nieves
}

\begin{abstract}
Lago Carite, a reservoir built in 1913 and owned by the Puerto Rico Electric Power Authority, has lost about 23 percent of its original storage capacity in 86 years. In 1913, the reservoir had about 13.95 million cubic meters of storage capacity, which decreased to 11.13 million cubic meters by 1986 and to 10.74 million cubic meters in 1999. This represents a long-term annual storage capacity loss of about 0.26 percent per year or about 0.037 million cubic meters per year. At this long-term sedimentation rate, the reservoir has a useful life of about 290 more years. This means that, if the sedimentation rate remains constant, by the year 2289 the reservoir would be filled with deposited material. The estimated trapping efficiency of the reservoir was calculated to be 97 percent for 1913, and 95 percent for 1986 and 1999, giving a long-term estimated trapping efficiency of about 96 percent. Using the long-term average trapping efficiency of the reservoir, the estimated sediment yield of the net sediment-contributing drainage area of 20.04 square kilometers (excluding the 1.20 square-kilometer surface area of the reservoir) is about 1,938 megagrams per square kilometer per year, assuming a dry-bulk density of sediments of 1 gram per cubic centimeter. The life expectancy of Lago Carite is not jeopardized in terms of water supply and recreation, however, sediment accumulation in the area adjacent to the power outlet could render the structure useless if not operated on a regular basis.
\end{abstract}

\section{Sumario}

El Lago Carite, un embalse construido en 1913 y propiedad de la Autoridad de Energía Eléctrica de Puerto Rico, ha perdido alrededor del 23 por ciento de su capacidad de almacenamiento original en el transcurso de 86 años. En 1913, el embalse tenía una capacidad de almacenamiento de alrededor de 13.95 millones de metros cúbicos, la que disminuyó a 11.13 millones de metros cúbicos para 1986, y a 10.74 millones de metros cúbicos para 1999. Esto representa una pérdida anual de capacidad de almacenamiento de 0.26 por ciento aproximadamente a largo plazo o unos 0.037 millones de metros cúbicos. A esta taza de sedimentación a largo plazo, la vida útil del embalse es de unos 290 años más. Esto significa que si la taza de sedimentación permaneciera constante, el embalse se llenaría de material depositado para el año 2289. La eficiencia estimada del embalse para atrapar sedimento fue 97 por ciento para 1913, y 95 por ciento para 1986 y 1999 , lo que constituye un promedio de eficiencia estimada para atrapar sedimento de 96 por ciento a largo plazo. Utilizando este promedio, el rendimiento de sedimento estimado del área neta de aportación de sedimento de 20.04 kilómetros cuadrados (excluyendo el área de superficie del embalse de 1.20 kilómetros cuadrados), es de unos 1,938 megagramos por kilómetro cuadrado al año, suponiendo que la densidad del volumen de sedimento desecado es de 1 gramo por centímetro cúbico. La expectativa de vida del Lago Carite no se encuentra amenazada en términos de abasto de agua y recreación. No obstante, la acumulación de sedimento en el área adyacente a la toma de electricidad podría inutilizar la estructura si no se opera con regularidad. 


\section{INTRODUCTION}

Lago Carite is a reservoir located in southeastern Puerto Rico, on the Río de la Plata, about 7 kilometers southeast of the town of Cayey (fig. 1). The reservoir was constructed in 1913 and is owned by the Puerto Rico Electric Power Authority (PREPA). Originally, Lago Carite was designed to provide about 13.95 million cubic meters of water for power generation at the Carite Hydroelectric System, which consists of three power plants; however, at this time the power plants are not operating. The power generation process was subordinated to the priorities of water supply for domestic and agricultural purposes. The reservoir now serves as water supply to the Guayama area, and provides irrigation water to the southeastern coastal plains of Puerto Rico by means of the east and west Guamaní canals. Recently, another water intake was constructed about 300 meters upstream from the dam at the right bank to provide water to the town of Cayey.

High annual average rainfall (2,032 millimeters) for the Lago Carite drainage area (Calvesbert, 1970) combined with agricultural land practices in the early 20th century have contributed to land erosion, causing large amounts of sediment to be transported through rivers and creeks to Lago Carite, depleting the storage capacity of the reservoir. Although the Lago Carite drainage area was declared a forest reserve in 1935 to protect the basins of the Río Grande de Loíza, the Río Grande de Patillas, and the Río de la Plata, agricultural practices that cause land erosion have not ended entirely. Vegetation is still being cleared to grow citrus and other minor fruit crops on private properties.

Also, an area of about 0.1 square kilometer (less than 1 percent of the total drainage area) was designated in 1936 by the Puerto Rico Department of Natural Resources to grow trees, which are later cut to produce lumber in a recurring fashion. As part of this process, vegetation is initially cleared to plant the trees. Later, the vegetation that grows under the canopy of the forest is cleared, leaving the soil unprotected.

The U.S. Geological Survey (USGS) in cooperation with PREPA conducted a bathymetric survey of Lago Carite during October 27 and 28, 1999, to determine the actual storage capacity of the reservoir, as well as sediment accumulation rates and sediment distribution within the reservoir. Data were collected using a Differential Global Positioning System (DGPS) coupled to a depth sounder, and then stored in a portable personal computer. The collected digital data were transferred into a Geographic Information System (GIS) for processing and analysis, and a triangulated irregular network (TIN) surface model of the reservoir bottom was created. From this model, the storage capacity and sediment accumulation in the reservoir were computed. Selected cross sections representing the reservoir bottom from shore to shore, longitudinal profiles along different branches of the reservoir, a bathymetric contour map, and a lake elevation-storage capacity curve and table were then generated from the TIN.

\section{DAM AND RESERVOIR CHARACTERISTICS}

The dam is an earth-filled structure with a crest elevation of 550.47 meters above mean sea level. The dam has a structural height of approximately 31.70 meters and a length of 152.40 meters. The spillway is an unlined, gently sloping channel excavated through the rock of a ridge in the left abutment. A concrete control sill, 36.58 meters in length, serves as the controlling spillway and is located near the upstream end of the channel at an elevation of 543.64 meters above mean sea level. The power outlet is located about 2,400 meters upstream from the dam, on the southern branch of the reservoir, with a footbridge to provide access from the reservoir shoreline.

Originally, water from this power outlet was released to the three power plants when they were operational; currently, water is released into east and west Guamaní canals to provide water for agricultural, commercial, domestic, and industrial uses in the southeastern part of Puerto Rico. The power outlet originally had one intake (elevation 529.59 meters above mean sea level), but sediment deposition disabled the opening.

Consequently, an additional inlet was constructed at a higher elevation (532.20 meters above mean sea level) to restore the ability to supply water to the canals. The dam sluice outlet work is located in the former diversion culvert, near the river level, through or along 


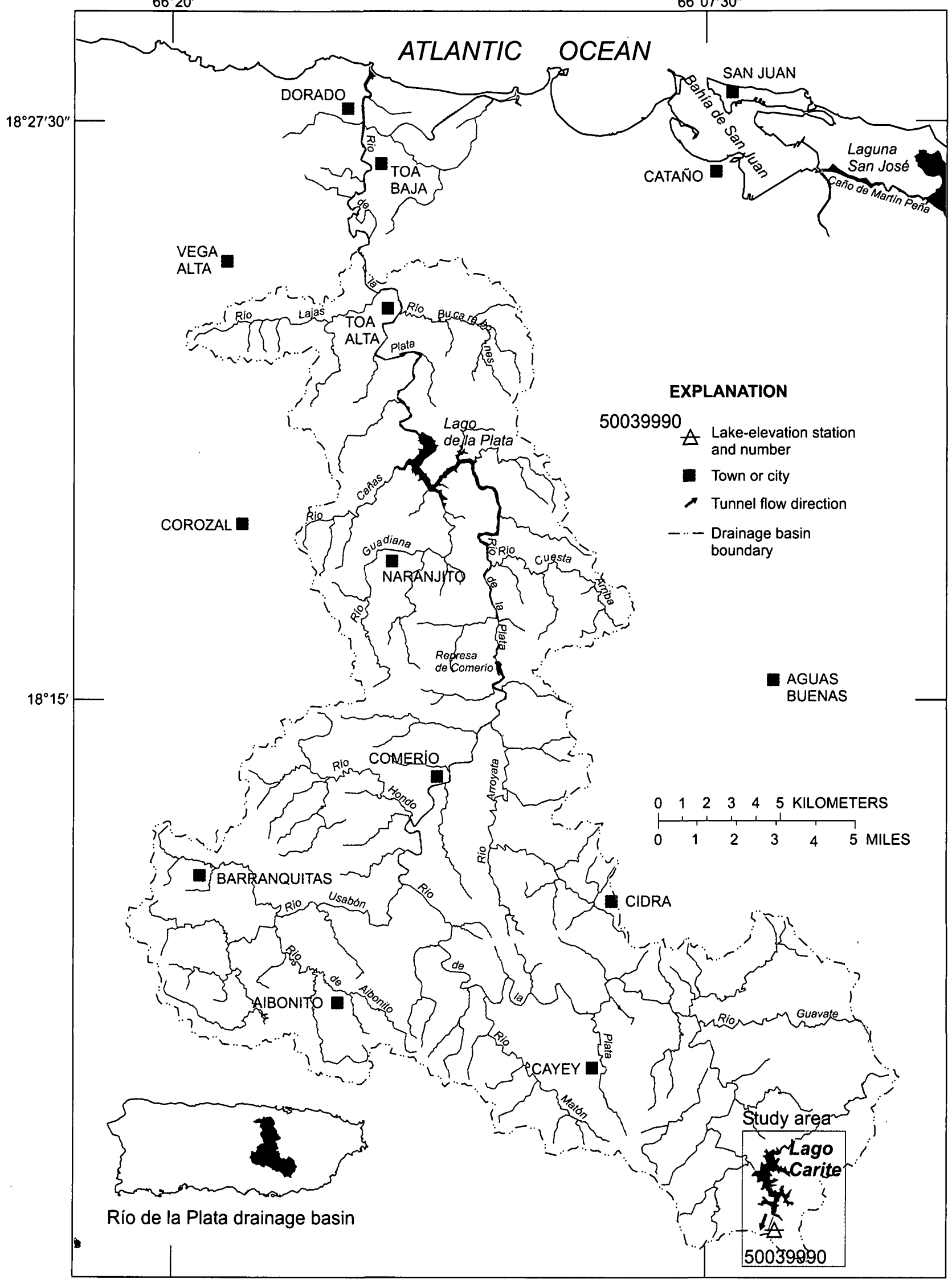

Figure 1. Location of Lago Carite in the Río de la Plata basin, Puerto Rico. 
the right abutment. Information on the culvert and its construction is incomplete; however, the culvert is believed to have been, in part, a reinforced concrete conduit constructed in a cut in the abutment formation and, in part, a tunnel (PREPA, 1988). Additional information for the reservoir and structures is presented in table 1 .

\section{METHOD OF SURVEY}

The bathymetric survey of Lago Carite involved planning, data collection, data processing, and analysis. A GIS (Arc/Info, Environmental Systems Research Institute, Inc., 1992) was used to plan the initial phases of the study and to analyze the collected data. Starting at the dam and continuing upstream along the different branches of the reservoir, 154 cross sections spaced 50 meters apart were planned to collect data in the reservoir (fig. 2). During the survey, positional and bathymetric data were collected using a DGPS interfaced with a depth sounder. The collected reservoir depth data were adjusted to represent depths below spillway elevation by using the USGS Lago Carite lake-level station at Gate Tower near Cayey (station 50039990).

Contour lines were drawn manually using the collected depth and positional data to represent the reservoir bottom in October 1999. These contours were then converted into a TIN surface model of the reservoir, and subsequently, from this model, the storage capacity of the reservoir was calculated using the GIS. A lake elevation-storage capacity curve was developed by calculating the reservoir volume at 1 -meter intervals of pool elevation.

Longitudinal profiles along the thalweg of the different branches of the reservoir and along selected cross sections from shore to shore were also generated from the TIN surface model to further characterize Lago Carite.

Table 1. Principal characteristics of Lago Carite and dam, Puerto Rico, as of 1988 (Modified from PREPA, 1988)

[Elevations in meters above mean sea level]

Total length of dam. 152.40 meters

Height of dam .31 .70 meters

Top width .6 .10 meters

Elevation of top of dam .550 .47 meters

Elevation of spillway crest. 543.64 meters

Tunnel intake elevation, top 531.42 meters

Tunnel intake elevation, invert. .529 .67 meters

Original 1913 spillway elevation capacity. .13 .95 million cubic meters

Original surface area at spillway elevation. .1 .35 square kilometers

Surface area in $1999^{1}$ 1.20 square kilometers

Drainage area at damsite ${ }^{2}$ .21 .24 square kilometers

Drainage area without reservoir surface area. 20.04 square kilometers

\footnotetext{
${ }^{1}$ Calculated from TIN surface model of Lago Carite, Puerto Rico.

2 From Díaz and others (1998).
} 


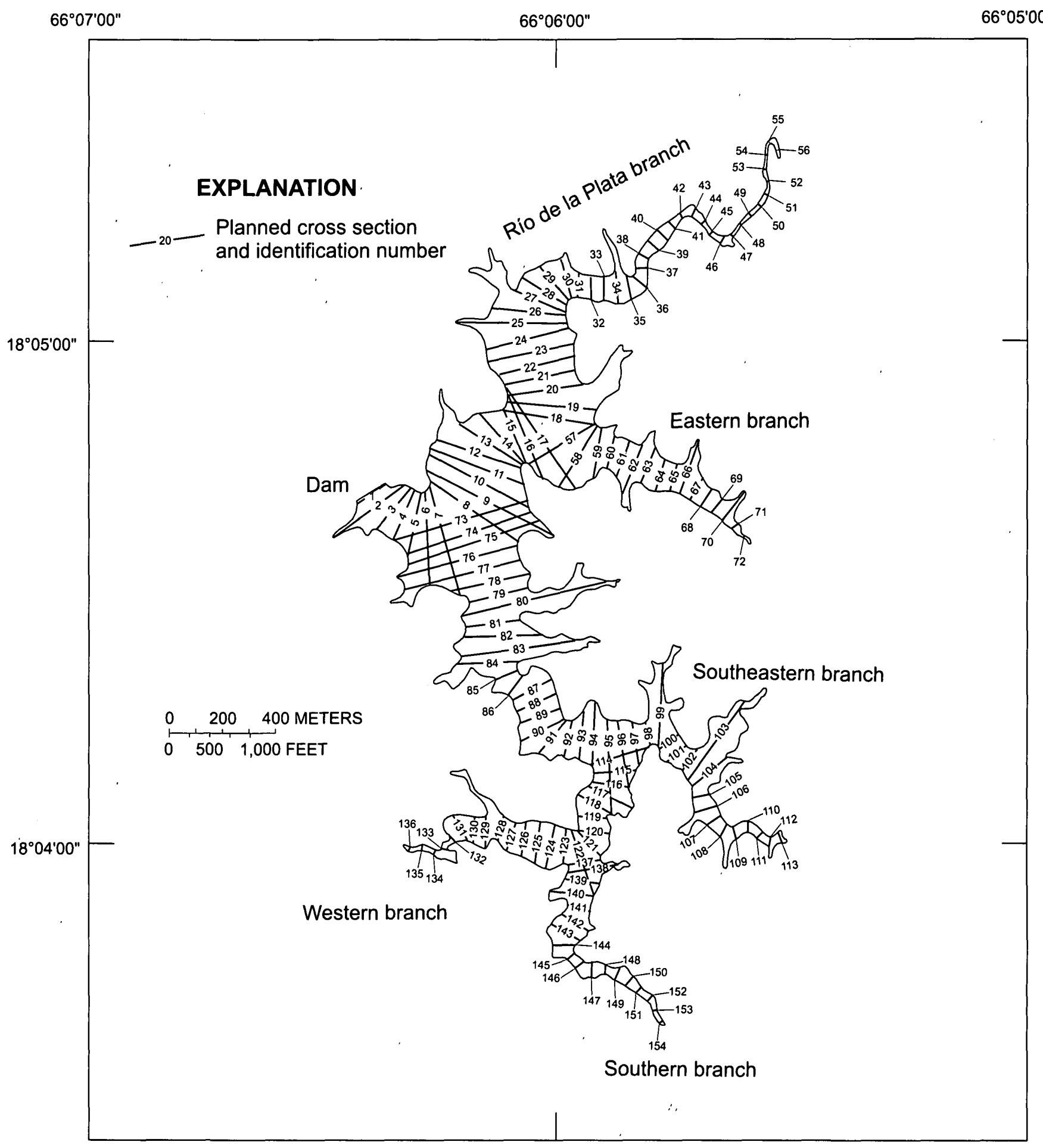

Figure 2. Planned cross-section locations for the 0 ctober 1999 bathymetric survey of Lago Carite, Puerto Rico. 


\section{Field Techniques}

The bathymetric survey of Lago Carite was carried out during October 27 and 28, 1999. Data were collected using the Bathymetric/Land Survey System (BLASS) developed by Specialty Devices, Inc. This system consists of two Novatel DGPS receivers to determine the horizontal position of the survey boat. The unit was first used in a static mode to establish reference marks at two sites overlooking the reservoir. From the known benchmark, PATILLAS 3 (lat. $17^{\circ} 59^{\prime} 12.1017^{\prime \prime} \mathrm{N}$., long. 6601'03.2417'W.), which was established by the local government agency Centro de Recaudación de Ingresos Municipales (CRIM), two new reference points, CAR-1 (lat. $18^{\circ} 04^{\prime} 52.7921$ N., long. $66^{\circ} 05^{\prime} 18.2076^{\prime \prime}$.') and CAR-2 (lat. $18^{\circ} 04^{\prime} 26.6497^{\prime \prime N}$., long.

$66^{\circ} 05^{\prime} 49.3866^{\prime \prime} \mathrm{W}$.), were established on hills overlooking the reservoir.

These benchmarks were later used as master stations for the remote stationary DGPS unit. The benchmark with the best view of the survey area was used as the remote DGPS site, and the other DGPS unit was mounted in the survey boat to serve as the mobile station. The mobile station independently calculated a position every second while receiving a set of pseudo-range correction signals every 5 seconds from the master station to maintain the positional precision of the survey boat within 2 meters. If the correction signal from the master station was lost, either a signal repeater was installed or a different benchmark was used as the master station to ensure the positional accuracy of the boat.

Water depths were measured using a BLASS-MSU-IDS Intelligent Depth Sounder, which collects depth data with an accuracy of 2 centimeters plus or minus 1 percent of the measured depth. The depth sounder was calibrated at water depths of 2, 4, 10 , and 14 meters. The bathymetric survey software, HYPACK, received and recorded water depths and geographic positions every second while in survey mode. The collected data were stored in the computer hard disk and were later transferred into the GIS. Plans were to collect data at 154 pre-established cross sections (fig. 2). However, low water depths and sediment accumulation in the riverine portions of the reservoir limited data collection to only 112 cross sections. A total of 14,264 data points were collected over the entire reservoir. Figure 3 shows the actual track lines where bathymetric data were collected for the October 1999 survey of Lago Carite. The longitudinal distances from the dam upstream to the different branches of the reservoir are shown in figure 4.

\section{Data Processing}

Initial editing of the depth and positional data was performed within the HYPACK program. Erroneous positions were corrected by eliminating anomalous spikes or "positional jumps" that occur when the correction signal from the stationary DGPS station is lost for a period of time. The correction signal can be lost because of physical obstructions, such as topographic features or because of electromagnetic interference. Where this occurred, the erroneous positions were interpolated between the correct anterior and posterior positions. Depth data were also corrected to eliminate erroneous depth readings collected by the fathometer. Floating debris and/or bubbles can interfere with the fathometer's transducer, causing erroneous depth readings. Incorrect readings were interpolated between the correct anterior and posterior depth values. If the amount of incorrect depth or positional data was substantial, the cross section was rerun.

The pool elevation of the reservoir changed slightly during the October 1999 bathymetric survey. To account for this change, the reservoir level was continuously monitored at the USGS lake-level station Lago Carite at Gate Tower, near Cayey (station 50039990). Then, a time-elevation correction factor was applied to the collected depth data to normalize them to depths below spillway elevation.

The edited data were then transferred into the GIS where data points were color coded according to different depth ranges. Then, data points with the same color were connected and a reservoir bathymetric contour map was generated (plate 1). The contour map of the reservoir was subsequently used to construct a TIN surface model of the reservoir. From the TIN surface model, selected cross sections representing the reservoir bottom depths from shore to shore and longitudinal profiles along the different branches of the reservoir were generated. 


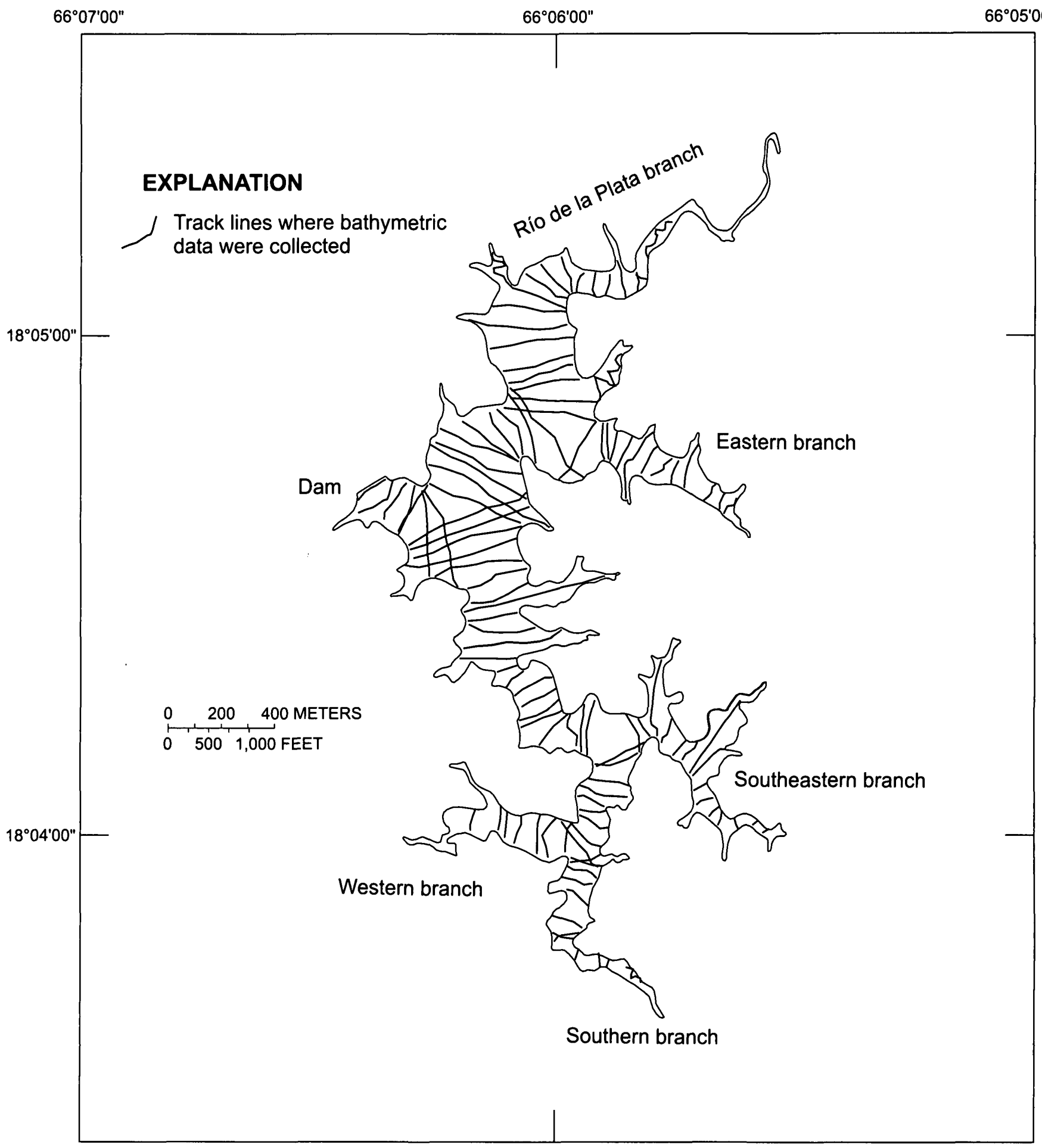

Figure 3. Actual track lines of the October 1999 bathymetric survey of Lago Carite, Puerto Rico. 


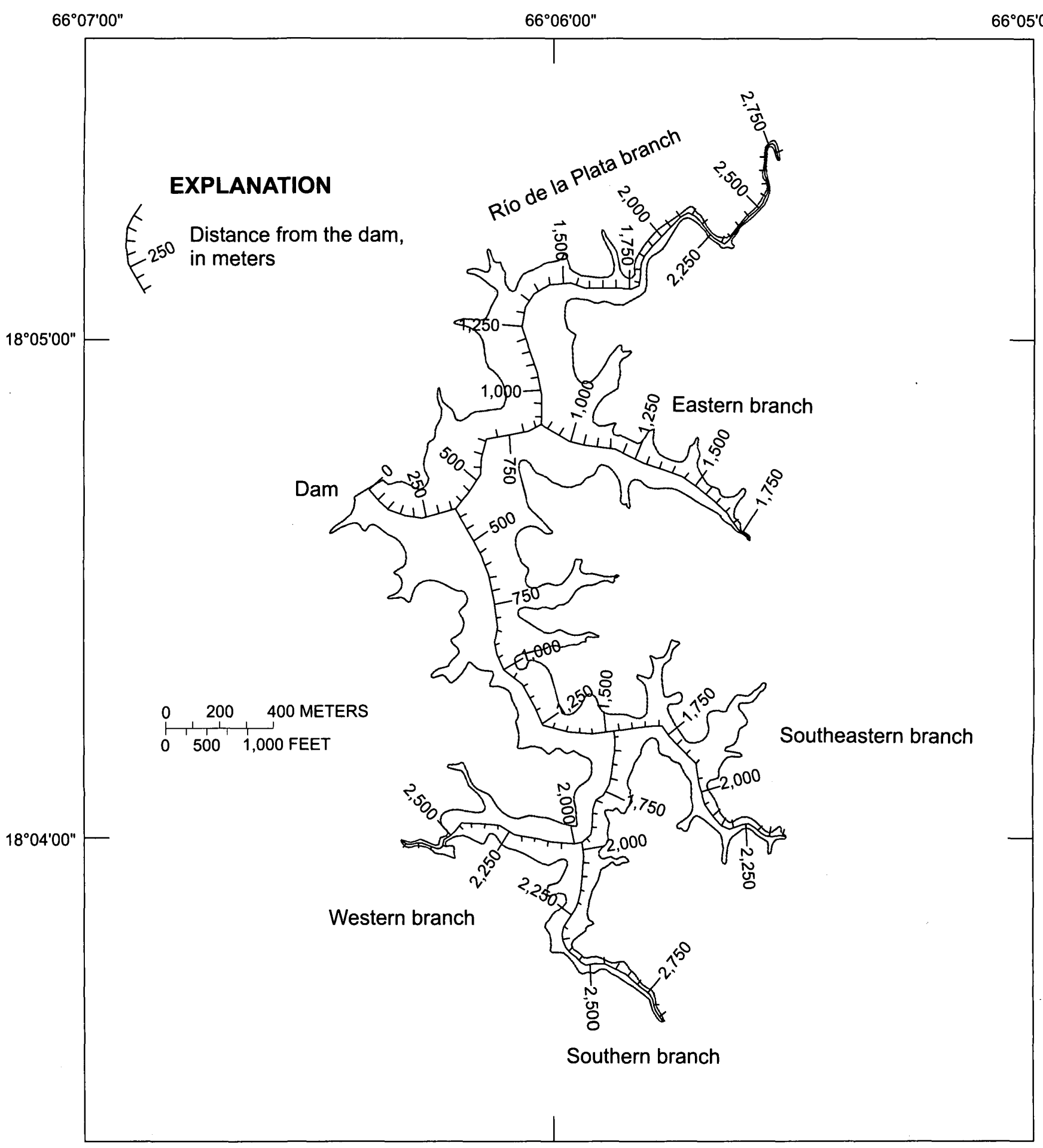

Figure 4. Distances from the dam along the different branches of Lago Carite, Puerto Rico. 


\section{ACTUAL CAPACITY AND SEDIMENT ACCUMULATION}

The storage capacity of Lago Carite has decreased from 13.95 million cubic meters in 1913 to 11.13 million cubic meters in 1986 (F. Quiñones, USGS, written commun., 1986) and to 10.74 million cubic meters in 1999. This represents a total reduction of 23 percent from the original volume or a sediment accumulation of about 3.21 million cubic meters in 86 years. The average long-term sedimentation rate of the reservoir is about 0.037 million cubic meters per year, or about 0.26 percent of capacity loss per year. At this long-term sedimentation rate, the reservoir will be completely filled with sediments in about 290 years. This means that if the sedimentation rate and the trapping efficiency of the reservoir were to remain constant, the reservoir would be filled with deposited material by the year 2289 . There was no information available on the methodology used for the 1913 survey (although standard land-surveying techniques before impoundment are presumed to have been used), whereas the range-line method was used in the 1986 survey. Results of the bathymetric survey of Lago Carite for 1913, the unpublished 1986 survey, and the October 1999 survey results are summarized in table 2 .
The survey results show that sediment accumulation in the reservoir has been moderate. Figure 5 shows selected cross-section locations, and figure 6 shows the selected cross sections generated from the TIN surface model of Lago Carite. In the cross sections presented in figure 6 , a flat bottom can be observed in several areas of the reservoir, indicating that sediment has accumulated in the original thalweg of the pre-impounded river channels. Sediment accumulation is more evident on the Río de la Plata branch of Lago Carite. In this branch, flat cross sections are observed from the riverine portion down stream to the dam, except at section 4 , which may be the result of increased water velocity generated during flood events and created by the channel contraction in this area. On the eastern and southern branches of the reservoir, the same pattern can be observed at a smaller scale. At the western branch, and principally at the southeastern branch of the reservoir, flat cross sections are not as evident (fig. 6, section 19). This suggests that there is little sediment transport and deposition in these branches. Figure 7 shows the longitudinal profiles along the thalweg of the different branches of Lago Carite. Shallow areas (reservoir deltas) are not clearly described in the figure because of the scale; they are better defined on plate 1 .

Table 2. Comparison of the 1913, 1986, and the October 1999 bathymetric surveys of Lago Carite, Puerto Rico

[---, not available or undetermined]

\begin{tabular}{llcc}
\hline & 1913 & 1986 & 1999 \\
\hline Storage capacity, in million cubic meters & 13.95 & 11.13 & 10.74 \\
Live storage, in million cubic meters ${ }^{1}$ & --- & -- & 9.17 \\
Dead storage, in million cubic meters & --- & -- & 1.57 \\
Years since construction & 0 & 73 & 86 \\
Storage capacity loss, in million cubic meters & 0 & 2.82 & 3.21 \\
Storage capacity loss, in percent & 0 & 20 & 23 \\
Storage capacity loss per year, in percent & 0 & 0.27 & 0.26 \\
Long-term sedimentation rate, in million cubic meters per year & 0 & 0.039 & 0.037 \\
Intersurvey sedimentation rate, in million cubic meters per year & 0 & 0.039 & 0.030 \\
\hline
\end{tabular}

\footnotetext{
${ }^{1}$ Calculated from TIN surface model of Lago Carite, Puerto Rico, and using the top elevation of the tunnel intake.
} 


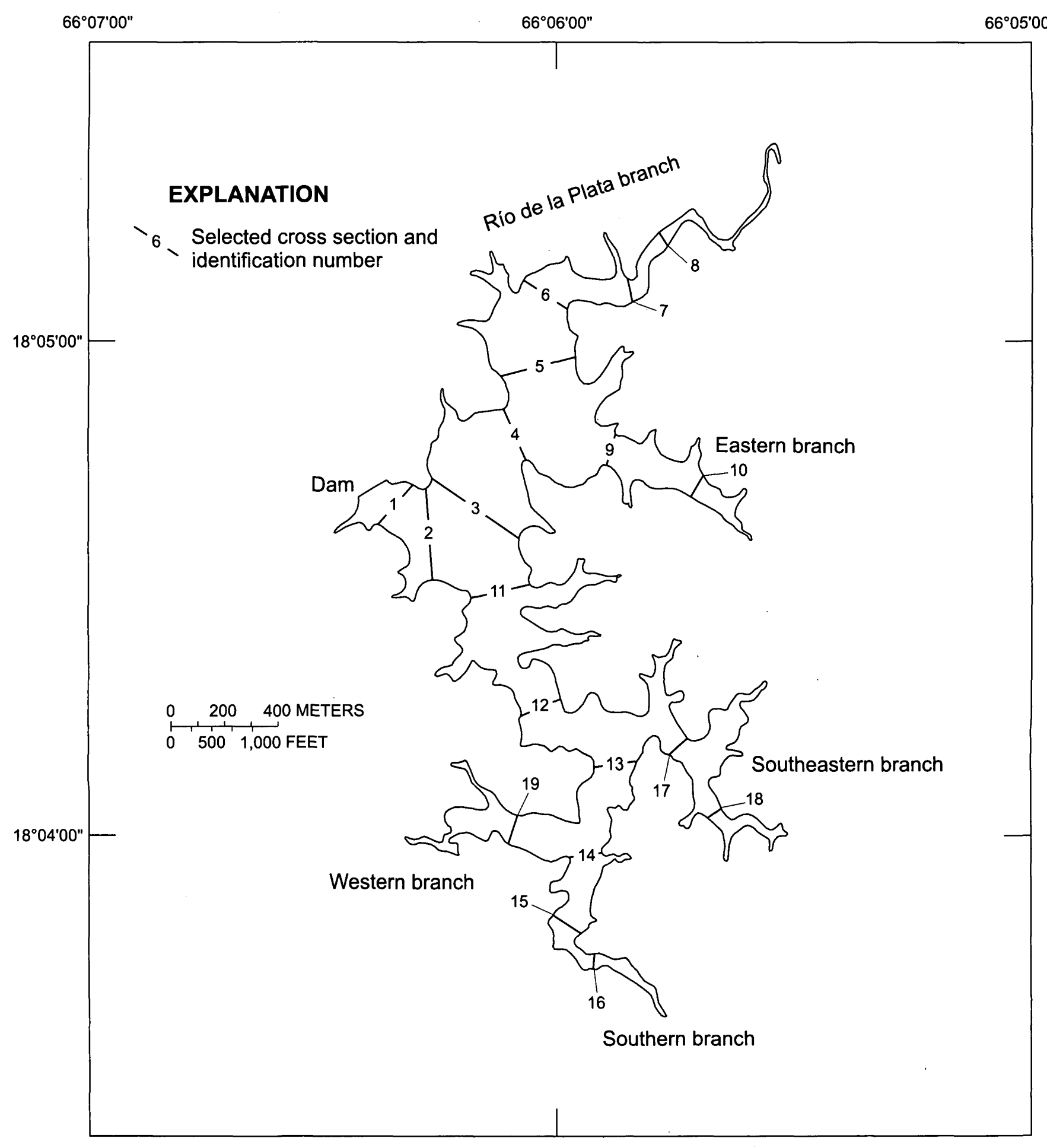

Figure 5. Selected cross-section locations for the October 1999 bathymetric survey of Lago Carite, Puerto Rico. 


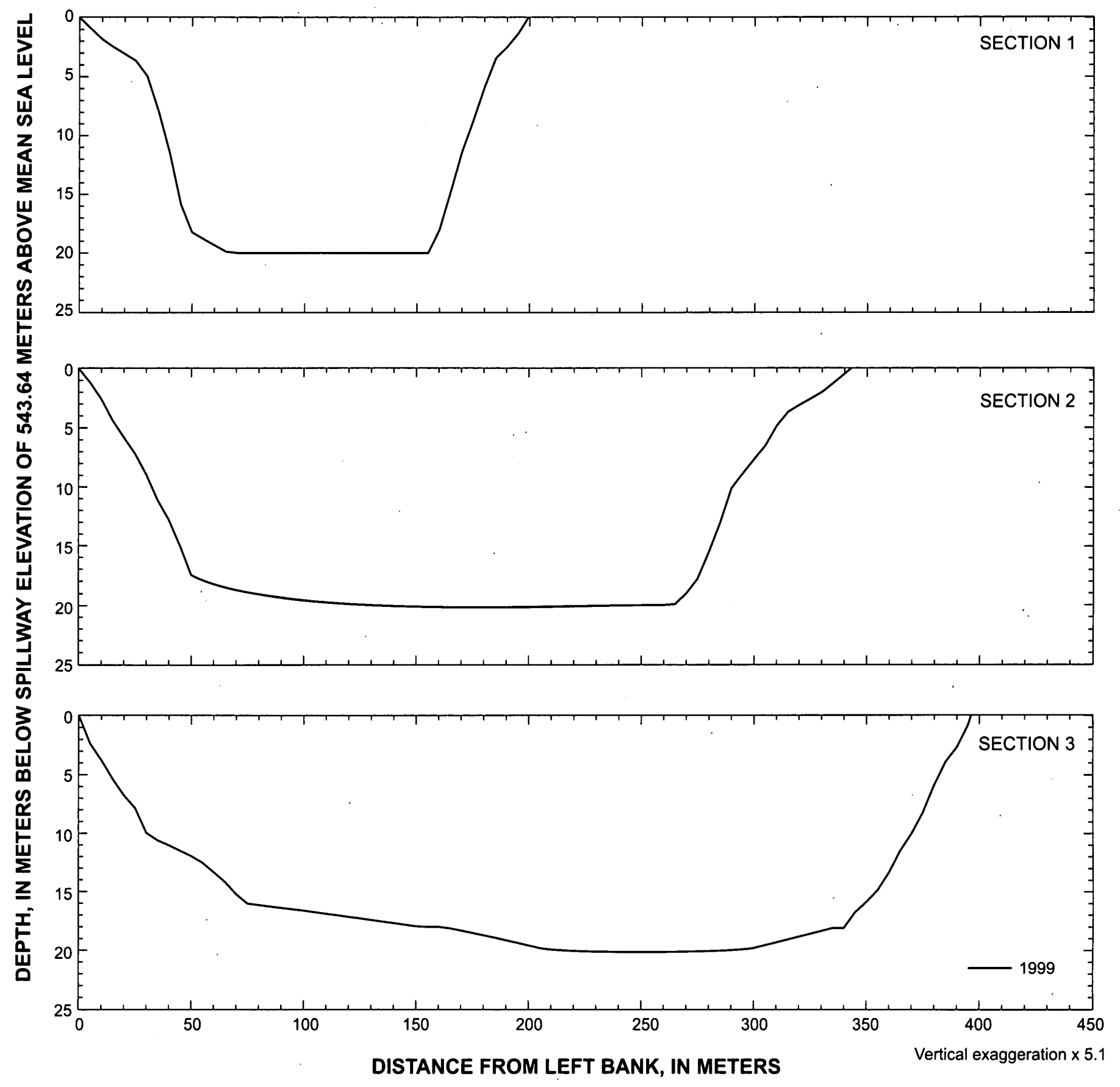

Figure 6. Selected cross sections generated from the October 1999 TIN surface model of Lago Carite, Puerto Rico. Refer to figure 5 for cross-section locations. 


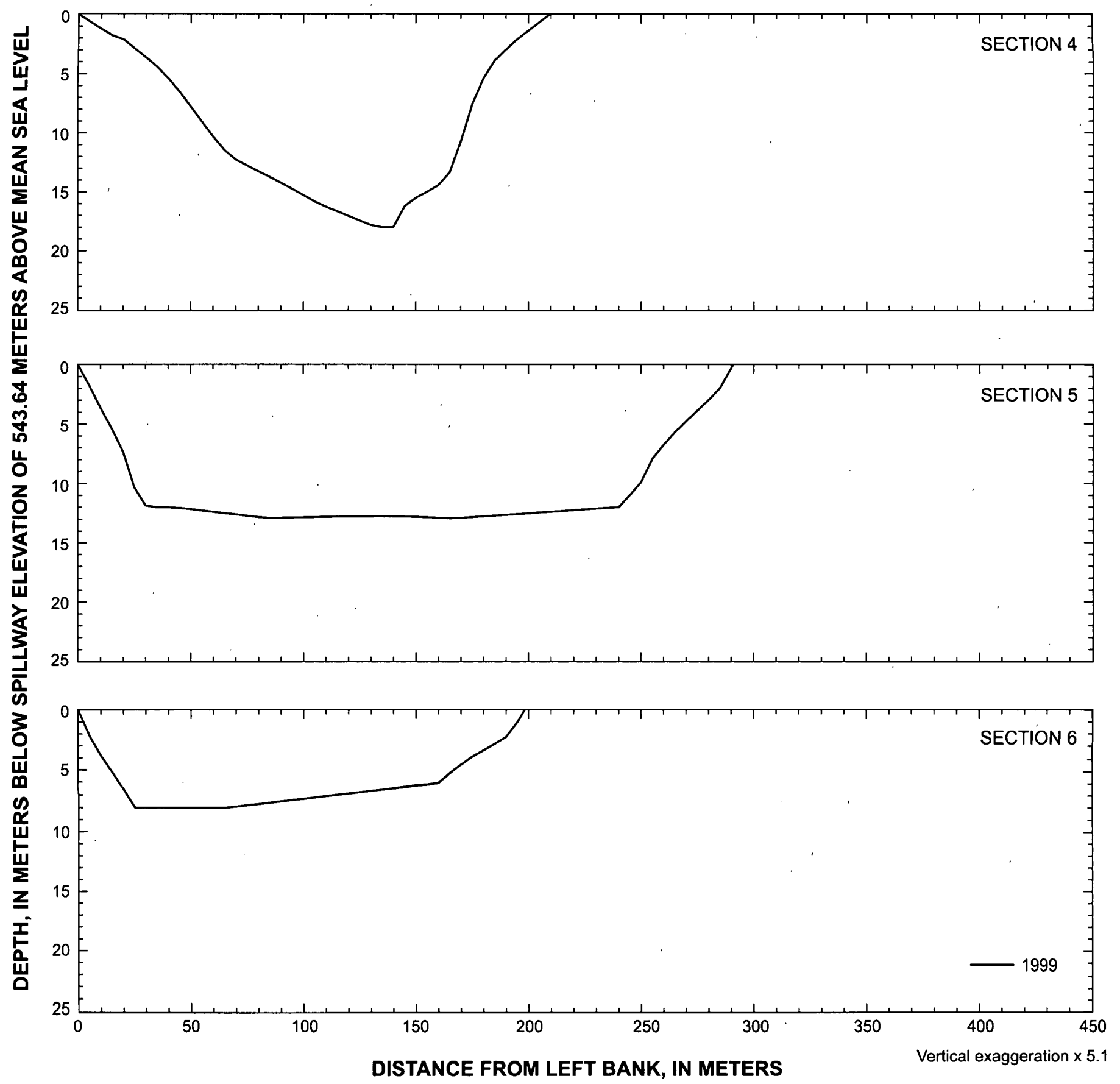

Figure 6. Selected cross sections generated from the October 1999 TIN surface model of Lago Carite, Puerto Rico-Continued. Refer to figure 5 for cross-section locations. 

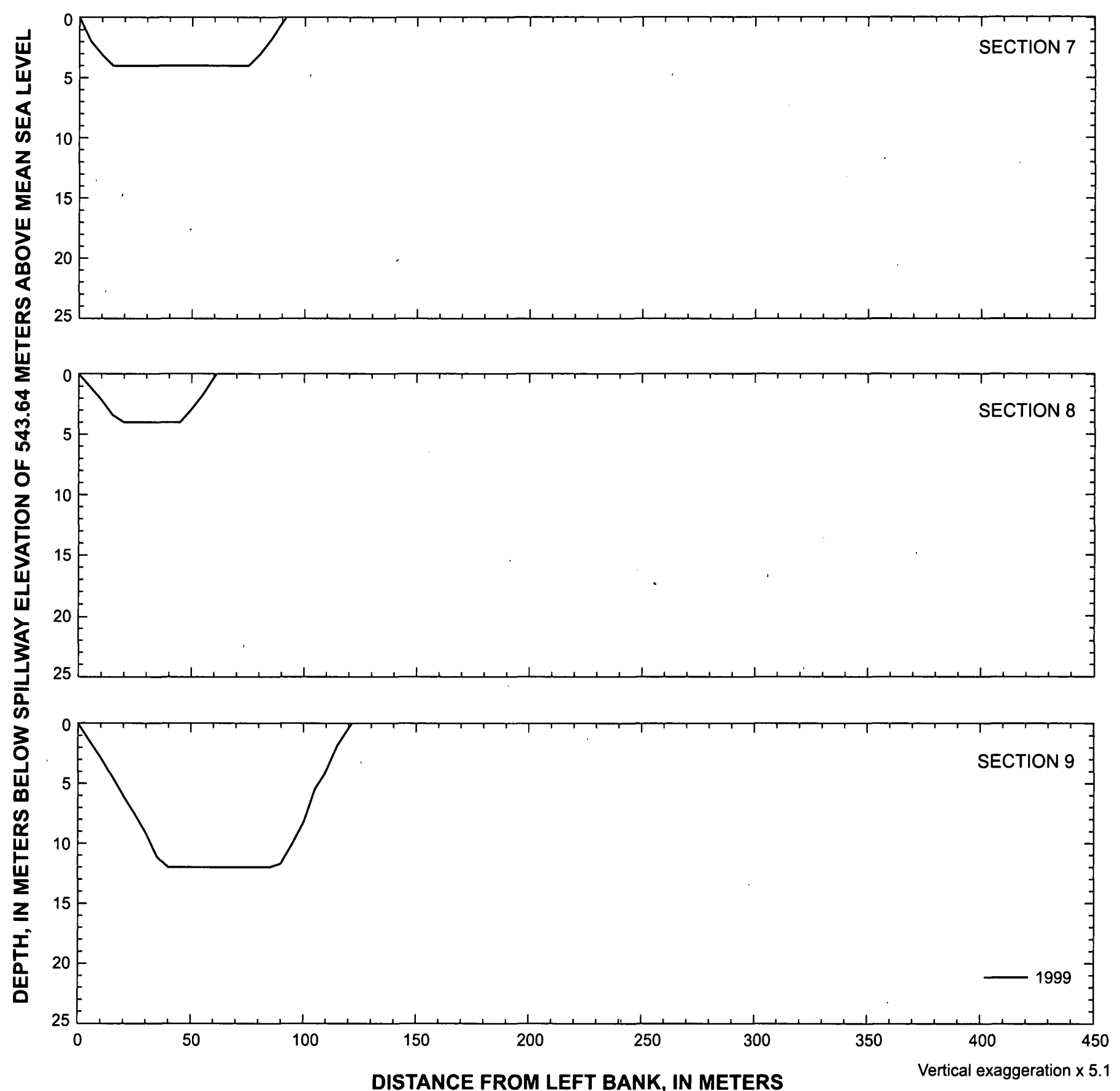

Figure 6. Selected cross sections generated from the October 1999 TIN surface model of Lago Carite, Puerto Rico-Continued. Refer to figure 5 for cross-section locations. 


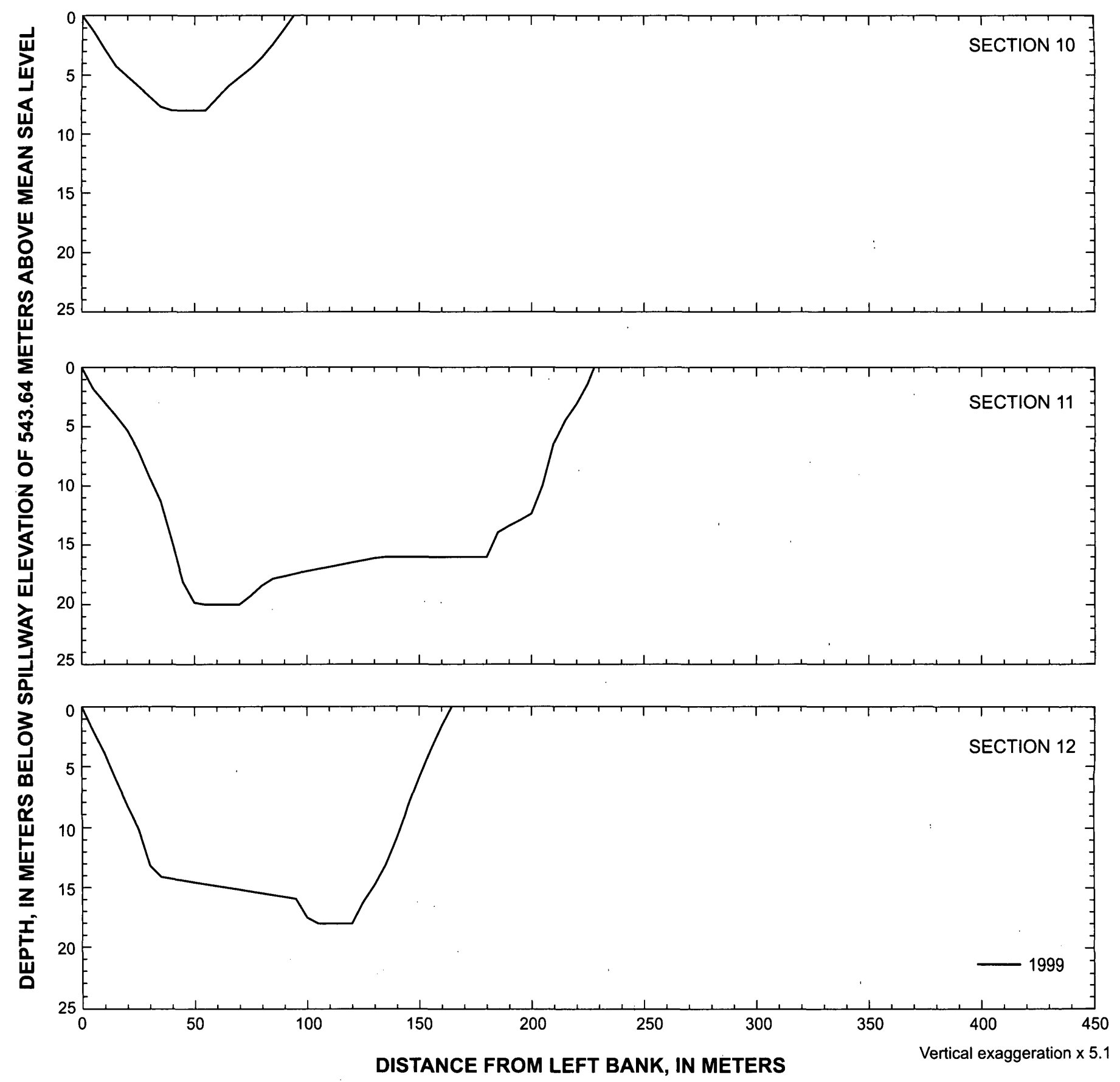

Figure 6. Selected cross sections generated from the October 1999 TIN surface model of Lago Carite, Puerto Rico-Continued. Refer to figure 5 for cross-section locations. 


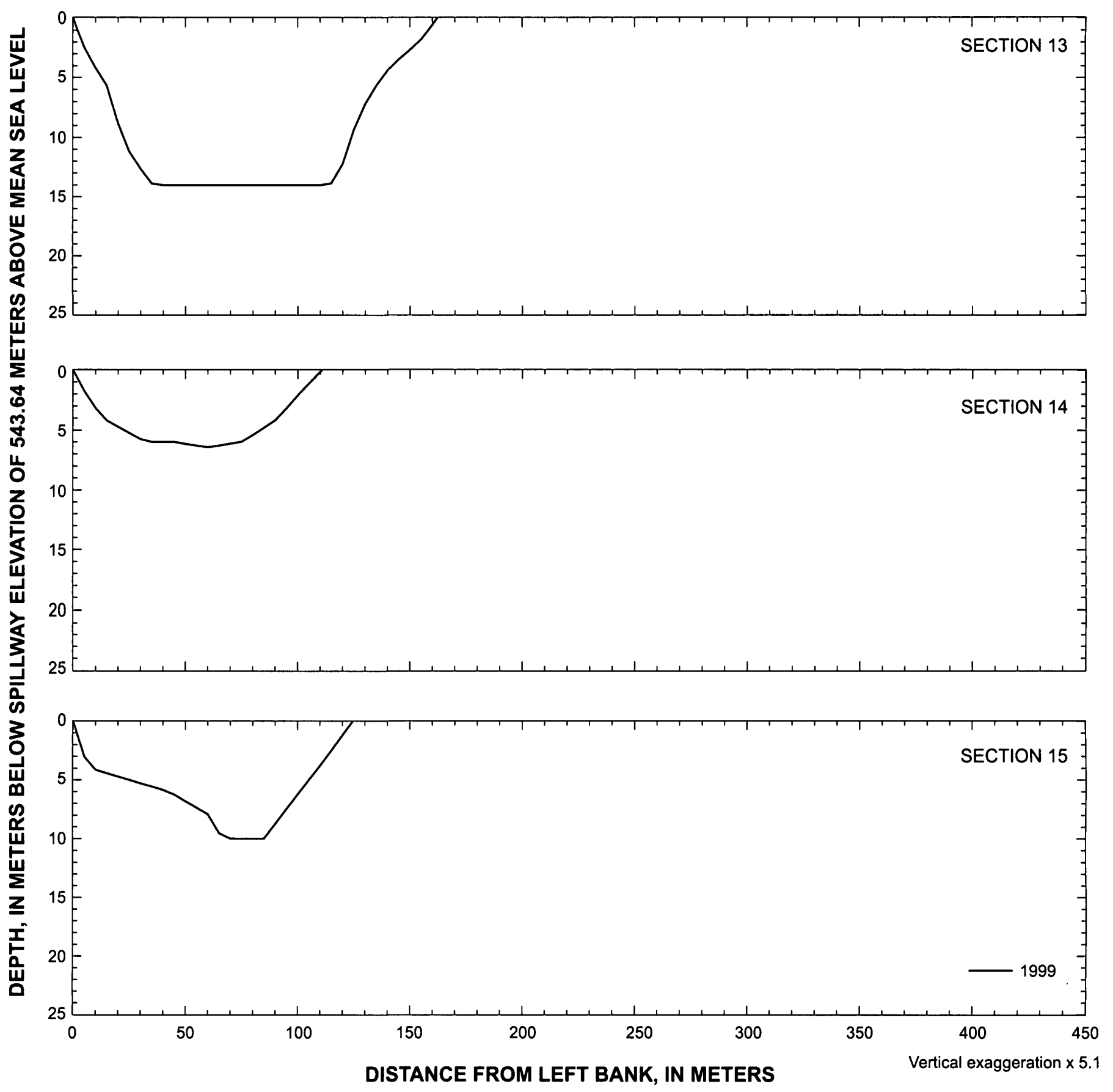

Figure 6. Selected cross sections generated from the October 1999 TIN surface model of Lago Carite, Puerto Rico-Continued. Refer to figure 5 for cross-section locations. 


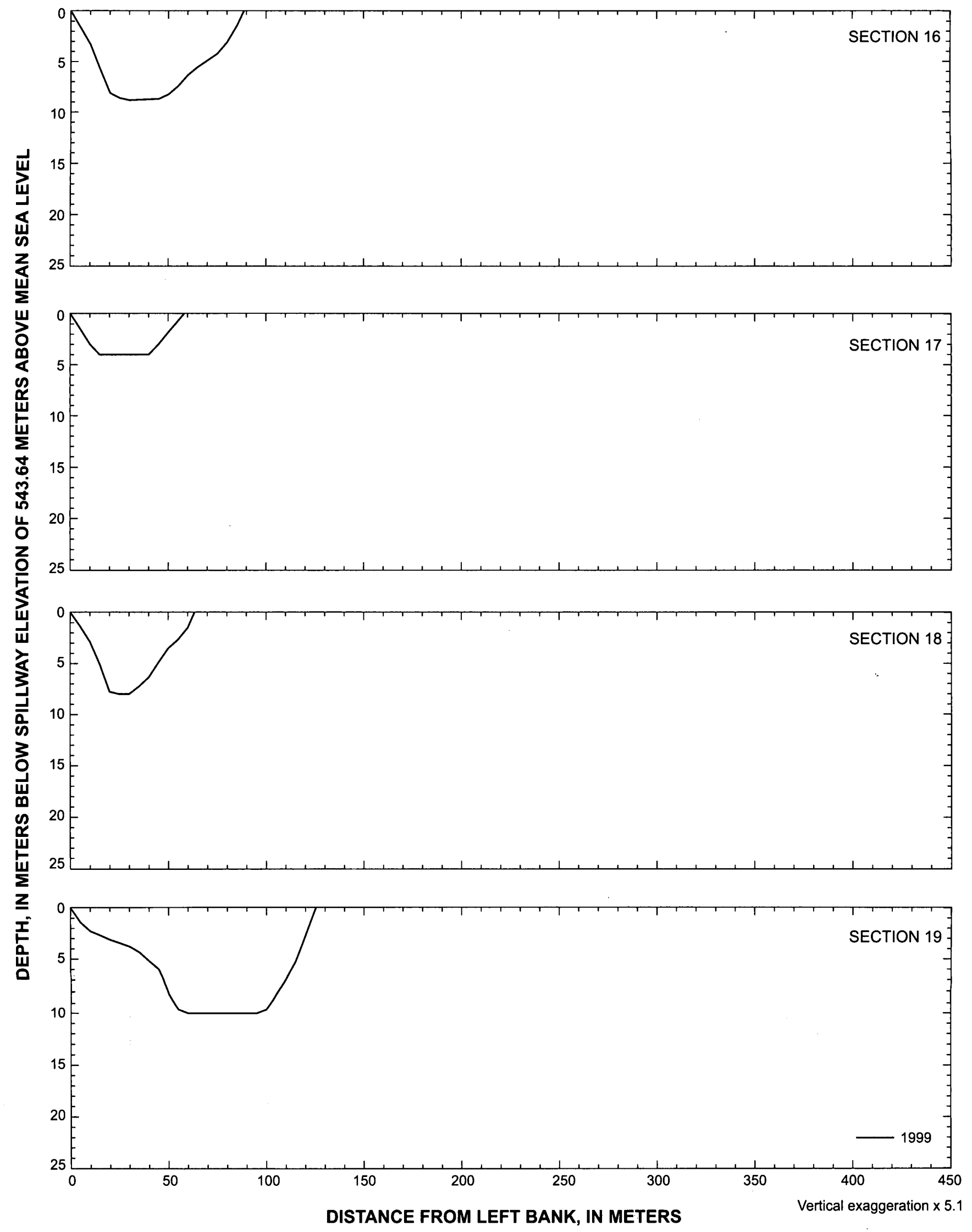

Figure 6. Selected cross sections generated from the October 1999 TIN surface model of Lago Carite, Puerto Rico-Continued. Refer to figure 5 for cross-section locations. 


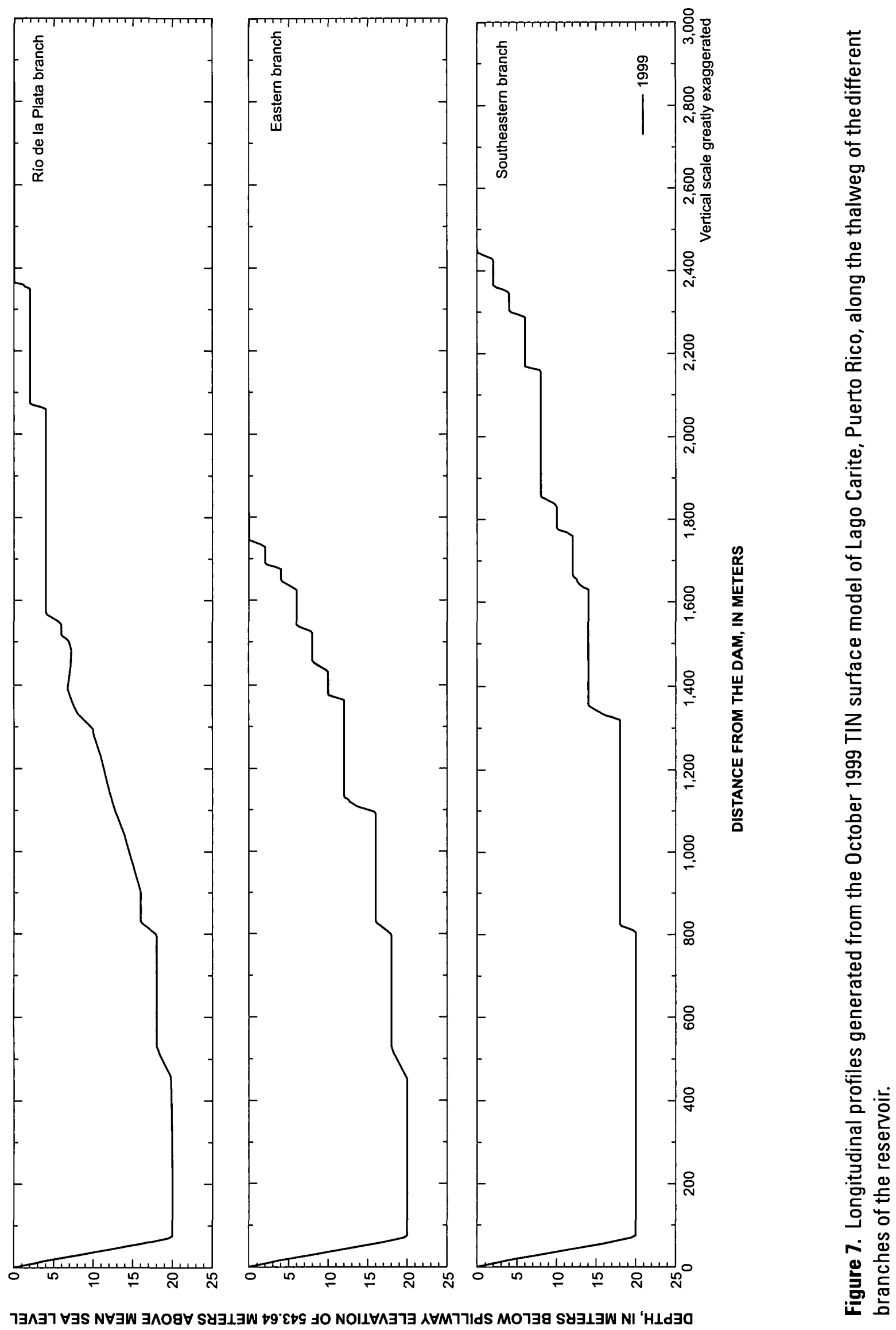




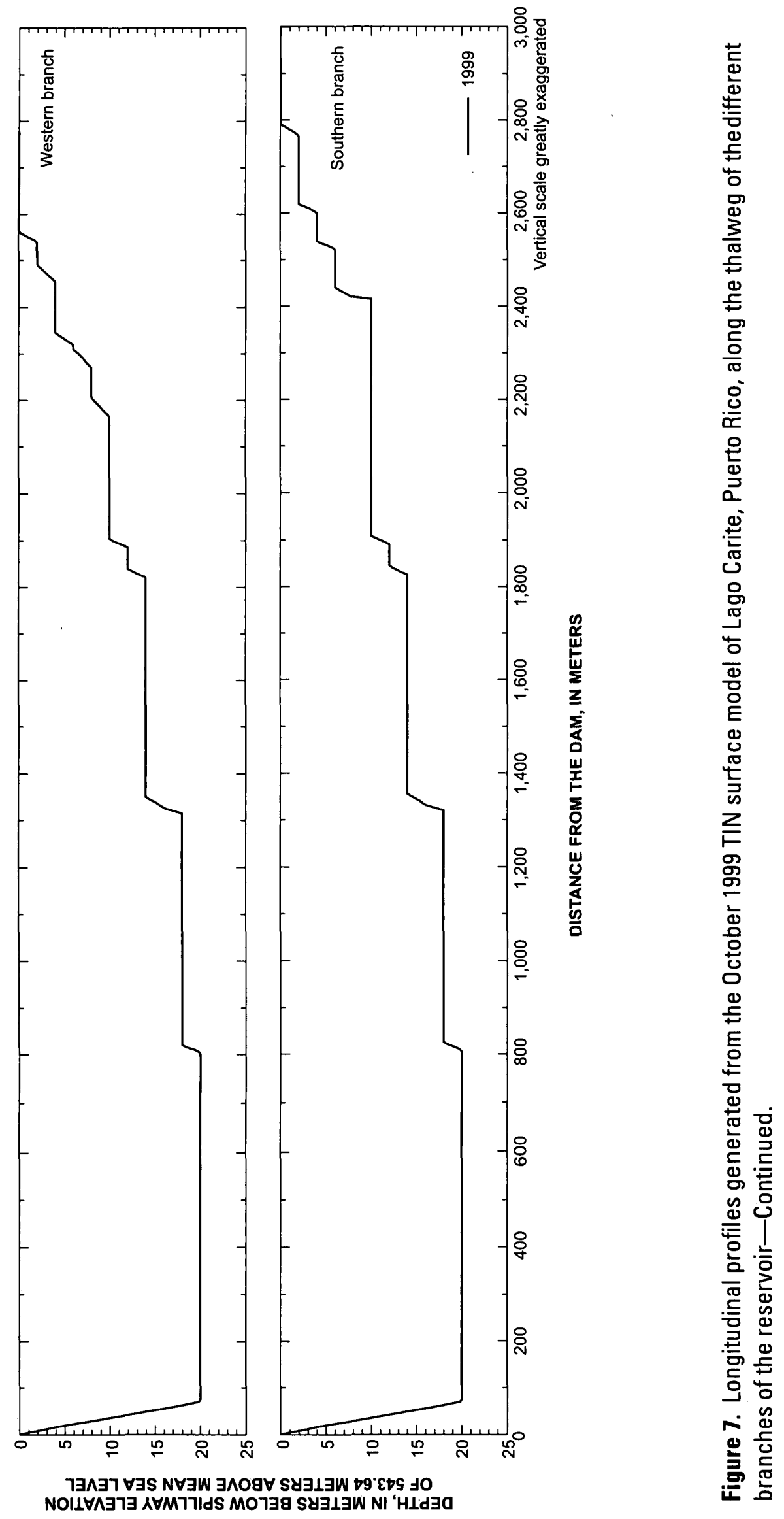


In the area adjacent to the power outlet, located about 2,400 meters upstream from the dam in the southern branch, the reservoir bottom has reached an elevation of about 537.64 meters above mean sea level, according to the October 1999 bathymetric map. This means that the higher intake of the structure (at elevation 532.20 meters above mean sea level) is surrounded by an accumulation of about 5.4 meters of deposited material. Although the structure is still operational, it is very likely that if not operated on a regular basis, the intake will be buried by sediment deposition. A capacity curve showing the relation between pool elevation and water volume for Lago Carite is presented in figure 8 and in tabular form in table 3.

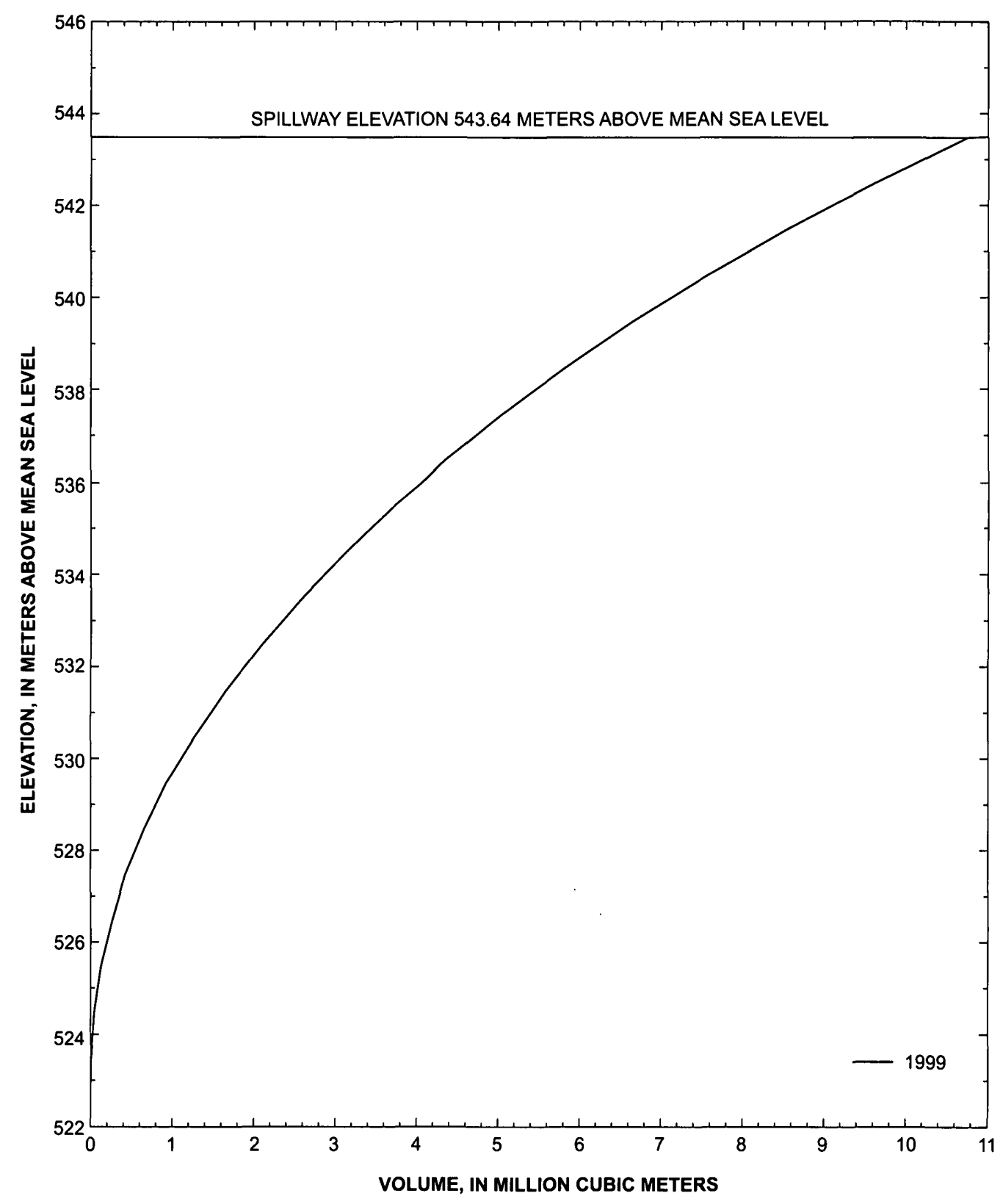

Figure 8. Lake elevation-storage capacity curve for Lago Carite, Puerto Rico, for October 1999. 
Table 3. Available storage capacity, as a function of lake elevation, for Lago Carite, Puerto Rico, October 1999

\begin{tabular}{cc}
\hline $\begin{array}{c}\text { Elevation, } \\
\text { in meters above mean sea level }\end{array}$ & $\begin{array}{c}\text { Storage capacity, } \\
\text { in million cubic meters }\end{array}$ \\
\hline 543.64 & 10.74 \\
542.64 & 9.60 \\
541.64 & 8.53 \\
540.64 & 7.55 \\
539.64 & 6.63 \\
538.64 & 5.81 \\
537.64 & 5.05 \\
536.64 & 4.35 \\
535.64 & 3.71 \\
534.64 & 3.12 \\
533.64 & 2.58 \\
532.64 & 2.09 \\
531.64 & 1.65 \\
530.64 & 1.27 \\
529.64 & 0.92 \\
528.64 & 0.65 \\
527.64 & 0.42 \\
526.64 & 0.26 \\
525.64 & 0.12 \\
524.64 & 0.04 \\
523.64 & 0.00 \\
\hline
\end{tabular}

\section{TRAPPING EFFICIENCY AND SEDIMENT YIELD}

The trapping efficiency of Lago Carite was estimated using the capacity/inflow ratio described by Brune in 1953. Brune (1953) developed a curve that estimates the trapping efficiency of a reservoir based on the relation between the reservoir volume and the mean annual inflow entering the reservoir (fig. 9). Because Lago Carite has no gaging station to measure the reservoir inflow, the drainage basin runoff was estimated from the neighboring basin of Río Guayanés, located about 7 kilometers east from the Lago Carite drainage area. Although the terrain type and land use have an influence on the runoff generated in a specific basin or drainage area, the two basins have a somewhat similar range of elevation and slope, and are in close proximity. Also, any land-use differences in the upper portions of the two drainage basins are considered to be negligible, since agricultural, industrial, and urban development is minimal in both basins.

USGS surface-water station records at Colonia Laura (station 50082800) show that the Río Guayanés drainage basin has a mean annual rainfall of 2,413 millimeters (Calvesbert, 1970) and a mean annual runoff of 2,184 millimeters for an 11-year period of record (USGS, 1982), giving a runoff-to-rainfall ratio of 0.90 . The Lago Carite drainage area has a mean annual rainfall of 2,032 millimeters (Calvesbert, 1970). Applying the same runoff-to-rainfall ratio for the Lago Carite catchment, the mean annual inflow to the reservoir is about 1,829 millimeters or about 38.87 million cubic meters. 


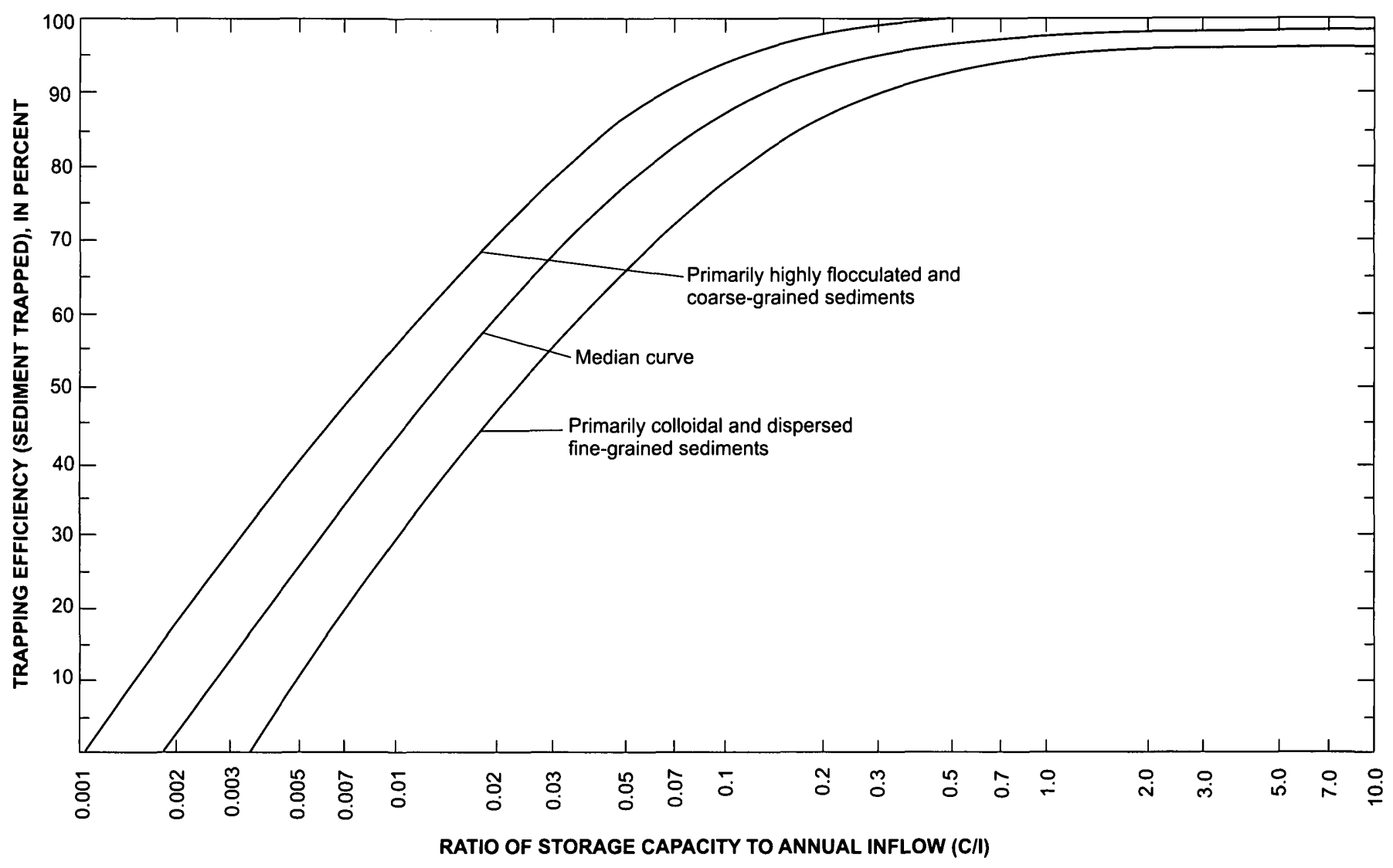

Figure 9. Storage capacity to inflow relation established by Brune (1953).

Based on the October 1999 storage capacity of 10.74 million cubic meters and the mean annual inflow of 38.87 million cubic meters, and using the median curve of Brune's relation, the trapping efficiency of Lago Carite is about 95 percent. Using the same relation, the trapping efficiency of Lago Carite was 97 percent for 1913 and 95 percent for 1986. The average long-term trapping efficiency of Lago Carite is about 96 percent.

Sediment yield has been defined by the American Society of Civil Engineers as the total sediment outflow from a catchment or drainage basin per unit of surface area, measurable at a point of reference and specified period of time (McManus and Duck, 1993). The total sediment accumulated in Lago Carite (3.21 million cubic meters) divided by the average long-term trapping efficiency of the reservoir (96 percent), gives the estimated amount of sediment that has been eroded from the reservoir drainage area in 86 years ( 3.34 million cubic meters). This number divided by the sediment-contributing area of the reservoir (20.04 square kilometers) and by the years since construction equals the estimated sediment yield of about 1,938 megagrams per square kilometer per year for Lago Carite, assuming a dry-bulk density of sediments of 1 gram per cubic centimeter. This relatively high historical sediment yield may be the result of land-use practices during the early decades of the 20th century; however, from 1986 to 1999 , the sediment yield of the reservoir basin has decreased to about 1,559 megagrams per square kilometer per year or a reduction of 19.6 percent. This reduction occurred in spite of Hurricanes Hortense (1996) and Georges (1998), which caused large increases in sedimentation rates in other reservoirs in Puerto Rico (Soler-López and others, 2000; Soler-López, 2000). Although the life expectancy of Lago Carite is not endangered in terms of water supply and recreation, sediment accumulation in the vicinity of the power outlet could render the structure useless if not operated on a regular basis. 


\section{REFERENCES}

Brune, G.M., 1953, Trap efficiency of reservoirs: Transactions of the American Geophysical Union, v. 34 , no. 3 , p. $407-418$.

Calvesbert, R.J., 1970, Climate of Puerto Rico and the U.S. Virgin Islands: U.S. Department of Commerce, Environmental Science Services Administration, $29 \mathrm{p}$.

Díaz, P.L., Aquino, Zaida, Figueroa-Álamo, Carlos, Vachier, R.J., and Sánchez, A.V., 1998, Water Resources Data, Puerto Rico and the U.S. Virgin Islands, Water Year 1998: U.S. Geological Survey Water Data Report PR-98-1, 629 p.

Environmental Systems Research Institute, Inc., 1992, Surface modeling with TIN, surface analysis and display: Redlands, Cal., 8 chapters.

McManus, J., and Duck, R.W., eds., 1993, Geomorphology and sedimentology of lakes and reservoirs: Chapter 6, Reservoir sedimentation rates in the Southern Pennine Region, UK: John Wiley \& Sons, New York, p. 73-92.
Puerto Rico Electric Power Authority, 1988, Carite Dam, Cayey, Puerto Rico: Phase 1- Inspection Report, Unit of inspection and regulation of dams and reservoirs of Puerto Rico: unpublished report, San Juan, PR, section 1, p. 1-6, 2, p. 1, and section 4, p. 1 .

Soler-López, L.R., 2000, Sedimentation survey of Lago Dos Bocas, Puerto Rico, October 1999: U.S. Geological Survey Water-Resources Investigations Report 00-4234, 18 p.

Soler-López, L.R., Webb, R.M.T., and CarrasquilloNieves, R.A., 2000, Sedimentation survey of Lago La Plata, Puerto Rico, October 1998: U.S. Geological Survey Water-Resources Investigations Report 00-4045, 23 p.

U.S. Geological Survey, 1982, Water-resources data for Puerto Rico, Water Year 1979-80: U.S. Geological Survey Water-Data Report PR-79-80, $408 \mathrm{p}$. 
District Chief

Caribbean District

U.S. Geological Survey

Water Resources Division

GSA Center, Suite 400-15

651 Federal Drive

Guaynabo, Puerto Rico 00965-5703 